PUSTABIBLIA: Journal of Library and Information Science

ISSN 2549-3493 (Print); ISSN 2549-3868 (Online)

DOI: http://dx.doi.org/10.18326/pustabiblia.v5i2.171-206

SK Dirjen Risbang-Kemristekdikti No 23/E/KPT/2019 (Peringkat 4 SINTA)

\title{
Pengaruh Kegiatan Pengembangan Profesi Terhadap Karier Pustakawan di Universitas Hasanuddin
}

\author{
Darmiati $^{1}$, Darmawari Nembo ${ }^{2}$, Sri Junandi ${ }^{3}$ \\ ${ }^{1,2}$ UPT Perpustakaan Univeristas Hasanuddin Makassar \\ ${ }^{3}$ Perpustakaan Universitas Gadjah Mada \\ Email: darmiharun@ymail.com
}

Naskah diterima: 04-11-2021, direvisi: 16-11-2021, disetujui: 17-11-2021

\begin{abstract}
Research purposes is analyze and describe the Effect of Professional Development of Librarians on Career Development of Librarians at Hasanuddin University. This research is quantitative. The research subject is Hasanuddin University librarian. Determination of respondents using purposive sampling method. The number of respondents was 48 civil servant librarians. Collecting data through the distribution of questionnaires and documentation. Descriptive statistical data analysis and multiple linear regression. The study found that partially only the innovative work of librarians affected the career development of librarians at Hasanuddin University. Meanwhile, self-development and scientific publications do not affect the career development of librarians at Hasanuddin University. Then simultaneously self-development, scientific publications and innovative works affect the career development of librarians at Hasanuddin University. Barriers to librarians in professional development are the lack of motivation of librarians; less confident; less focus; ability or knowledge and skills; limited time due to work; less productivity due to environmental factors; limited budget and forum for professional development activities; lack of attention and appreciation from the leadership or agency. Meanwhile, the lack of opportunity and narrow insight is not an obstacle. Furthermore, the obstacles for librarians in career development are lack of strength or ability, feeling satisfied with the position they have, lack of cooperation
\end{abstract}


or a supportive network in their environment. Meanwhile, unsure of the librarian's competence, lack of responsibility such as lazy, likes to be late, often not in the office; lack of strength or ability; lack of information is not obstacle for librarians in career development activities.

Keywords: librarian; professional development; career development

\begin{abstract}
ABSTRAK
Penelitian ini bertujuan untuk menganalisis dan menggambarkan pengaruh kegiatan pengembangan profesi terhadap karier pustakawan di Universitas Hasanuddin. Penelitian ini bersifat kuantitatif. Subjek penelitian adalah pustakawan Universitas Hasanuddin. Penentuan responden menggunakan metode purposive sampling. Jumlah responden sebanyak 48 pustakawan PNS. Pengumpulan data melalui penyebaran kuesioner dan dokumentasi. Analisis data statistik deskriptif dan regresi linear berganda. Penelitian menemukan, bahwa secara parsial hanya karya inovatif pustakawan berpengaruh terhadap perkembangan karier pustakawan di Universitas Hasanuddin. Sementara, pengembangan diri dan publikasi ilmiah tidak berpengaruh terhadap perkembangan karier pustakawan di Universitas Hasanuddin. Kemudian secara simultan pengembangan diri, publikasi ilmiah dan karya inovatif berpengaruh terhadap perkembangan karier pustakawan di Universitas Hasanuddin. Hambatan pustakawan dalam pengembangan profesi adalah kurangnya motivasi pustakawan; kurang percaya diri; kurang fokus; kemampuan atau pengetahuan dan keterampilan; terbatasnya waktu karena pekerjaan; kurang produktivitas karena faktor lingkungan; terbatasnya anggaran dan wadah untuk kegiatan pengembangan profesi; kurangnya perhatian dan apresiasi dari pimpinan atau instansi. Sementara itu, kurangnya kesempatan dan wawasan sempit bukan merupakan hambatan. Selanjutnya, hambatan pustakawan dalam pengembangan karier adalah kurangnya kekuatan atau kemampuan, merasa puas dengan jabatan yang dimiliki, kurangnya kerjasama atau jaringan yang mendukung di lingkungannya. Sementara itu, tidak yakin dengan kompetensi pustakawan, kurangnya tanggung jawab seperti malas, suka terlambat, sering tidak berada dikantor; kurangnya kekuatan atau kemampuan; dan kurangnya informasi bukan merupakan hambatan bagi pustakawan dalam kegiatan perkembangan karier.
\end{abstract}

Kata kunci: pustakawan; pengembangan profesi; pengembangan karier 


\section{PENDAHULUAN}

Perpustakaan dalam menjalankan kegiatannya membutuhkan sumber daya manusia yang memiliki kompetensi dan profesional dalam bidangnya yaitu pustakawan. Pustakawan merupakan jabatan fungsional karena memiliki kompetensi yang diperoleh melalui pendidikan dan pelatihan, serta pelaksana dalam tugas utama bidang kepustakawanan. "Kepustakawanan adalah kegiatan ilmiah dan profesional yang meliputi kegiatan pengelolaan perpustakaan, pelayanan perpustakaan, dan pengembangan sistem kepustakawanan". ${ }^{1}$ Berdasarkan data UPT Perpustakaan Universitas tahun 2020 bahwa jumlah pejabat fungsional pustakawan di lingkungan Universitas Hasanuddin sebanyak 4 orang jabatan Tingkat Terampil dan 40 orang Tingkat Ahli. Data tersebut menunjukkan bahwa Universitas Hasanuddin sudah memiliki tenaga pustakawan yang cukup sesuai dengan standar berdirinya perpustakaan perguruan tinggi. "Standar berdirinya perpustakaan perguruan tinggi dalam buku Pedoman Penyelenggaraan Perpustakaan Perguruan Tinggi Tahun 2015 dijelaskan bahwa perpustakaan dikelola oleh tenaga perpustakaan paling kurang 2 orang pustakawan; untuk 500 mahasiswa pertama: 1 orang pustakawan dan 1orang staf;untuk setiap tambahan 200 mahasiswa, ditambah 1 orang pustakawan".

Perkembangan ilmu pengetahuan, ledakan informasi dan terknologi informasi yang sangat pesat dan cepat, mutu kinerja pustakawan dan kinerja institusi, serta jabatan fungsional merupakan tantangan bagi profesi pustakawan dalam menjalankan kegiatannya. Tuntutan tersebut, mengharuskan pustakawan untuk melakukan pengembangan profesi. "Pengembangan profesi adalah pengembangan pengetahuan, keahlian, keterampilan, sikap dan bakat yang bermanfaat untuk profesi pustakawan dalam melaksanakan tugas kepustakawanan". ${ }^{3}$ Tujuan

${ }^{1}$ Peraturan Menteri Pendayagunaan Aparatur Negara dan Reformasi Birokrasi Republik Indonesia Nomor 9 Tahun 2014 tentang Jabatan Fungsional Pustakawan dan Angka Kreditna,, Pasal 1.

${ }^{2}$ Perpustakaan Nasional Republik Indonesia. Pedoman Penyelenggaraan Perpustakaan Perguruan Tinggi Tahun 2015.

${ }^{3}$ Peraturan Kepala Perpustakaan Nasional Republik Indonesia Nomor 11 Tahun 2015 tentang Petunjuk Teknis Jabatan Fungsional Pustakawan dan Angka Kreditnya. 
pengembangan profesi pustakawan adalah untuk meningkatkan kompetensi, kualitas kerja dan kinerja institusi dan karier pustakawan.

Kegiatan pengembangan profesi perlu dilakukan oleh semua pustakawan. Kegiatan tersebut meliputi pengembangan diri, publikasi ilmiah dan karya inovatif. Pengembangan diri merupakan bentuk perwujudan dari aktualisasi diri, yaitu sebuah bentuk keinginan yang dimiliki pustakawanakan kemampuan dirinya untuk mencapai tujuan yang diingikan. Publikasi ilmiah adalah karya tulis yang telah dihasilkan oleh pustakawan dan dipublikasikan kepada masyarakat, baik bentuk tercetak maupun elektronik. Karya inovatif pustakawan adalah suatu karya pengembangan kepustakawanan yang bersifat penemuan baru seperti penemuan teknologi informasi perpustakaan, pengemasan informasi dari bentuk cetak ke digital, penyusunan standar, pedoman dan sejenisnya. Kegiatan pengembangan profesi pustakawan merupakan dampak nyata yang memerlukan dukungan dari institusi atau lembaga induknya dalam rangka meningkatkan kinerja perpustakaan, mutu kerja, keberadaan profesi pustakawan dan perkembangan karier.

Pengembangan karier pustakawan adalah proses kemampuan aktivitas yang dilakukan oleh pustakawan untuk mempersiapkan diri dalam kemajuan jalur karier yang direncanakan dan diharapkan. Dengan adanya pengembangan karier tersebut, sehingga pustakawan akan mendapatkan hak-hak yang lebih baik dari apa yang diperoleh sebelumnya. Rivai (2014) berpendapat bahwa "pengembangan karier adalah serangkaian proses peningkatan kemampuan kerja individu yang dicapai dalam rangka mencapai karir yang diinginkan yang bertujuan menyesuaikan antara kebutuhan dan tujuan karyawan dengan kesempatan karir yang tersedia di perusahaan saat ini dan di masa yang akan dating". Sejalan dengan pendapat Nawawi (2016) bahwa "pengembangan karier merupakan usaha formal untuk meningkatkan dan menambah kemampuan, yang diharapkan bedampak pada pengembangan dan perluasan wawasan, yang membuka kesempatan mendapatkan posisi/jabatan yang memuaskan dalam kehidupan

${ }^{4}$ Veithzal Rivai, Manajemen Sumber Daya Manusia Untuk Perusahaan: Dari Teori ke Praktek (Jakarta: RajaGrafindo Persada, 2014). 
sebagai pekerja dengan tujuan memperbaiki dan meningkatkan efektivitas pelaksanaan pekerjaan, agar semakin mampu memberikan kontribusi terbaik dalam mewujudkan tujuan organisasi". ${ }^{5}$

Namun kondisi saat ini, banyak pustakawan, khususnya pustakawan yang ada di lingkup Universitas Hasanuddin, belum menjalankan kegiatan pengembangan profesi sebagaimana mestinya. Sementara itu, pengembangan profesi sangatlah penting bagi pustakawan dalam perkembangan karier ke jenjang lebih tinggi, serta dapat mewujudkan sumber daya mansuia perpustakaan yang kompeten dan berkualitas. Menurut Wuryandini (2014) bahwa "permasalahan yang dihadapi kegiatan PKB antara lain dikemukakan oleh Kepala Dinas Pendidikan Kota Semarang, Ketua MGMP, Kepala Sekolah dan Guru bahwa: guru memiliki karakteristik yang berbeda (individu dan lingkungan ); belum adanya sosialisasi diklat workshop tentang pengembangan diri publikasi ilmiah, dan karya inovatif; terbatasnya anggaran; kurangnya kesiapan dan komitmen untuk mengikuti pengembangan; kesempatan tidak berkelanjutan ; kurangnya motivasi; metode pelatihan dan workshop

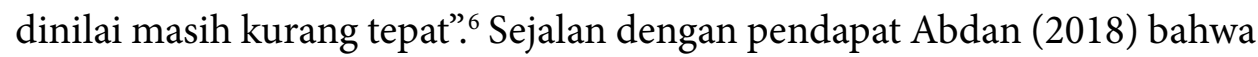
"kendala dalam melakukan kegiatan menulis dipengaruhi oleh faktor internal mencakup kurangnya motivasi, tidak memiliki ide, tidak percaya diri, kurang fokus, wawasan yang sempit, tidak berbakat, kurang menguasai kebahasaan, merasa puas sebagai konsumen. Faktor eksternal yaitu tidak mempunyai waktu, lingkungan tidak kondusif, terbatasnya wadah pelatihan, kurangnya apresiasi. Namun demikian, keterampilan menulis itu tidak akan dikuasai hanya melalui teori saja tetapi harus dilaksanakan melalui latihan dan praktek yang teratur diimbangi dengan membaca yang banyak, mendengarkan dengan cermat, dan menulis yang banyak"?

${ }^{5}$ Hadari Nawawi, Manajemen Sumber Daya Manusia: untuk bisnis yang kompetitif (Yogyakarta: Gadjah Mada Universitas Press), hal. 289

${ }^{6}$ Endang Wuryandini, Analisis Permasalahan dan Kebutuhan Pengembangan Keprofesian Berkelanjutan Guru SMK Bidang Keahlian Bisnis dan Manajemen Pascasertifikasi di Kota Semarang. Jurnal Manajemen Pendidikan, Vol. 9, No. 2(2014): 108-119. https://journals.ums.ac.id

${ }^{7}$ Fahrizandi Abdan, Problematika Pustakawan dalam Menulis Karya Tulis Ilmiah Fahrizandi Abdan. Jurnal Libraria, Vol. 6, No.1(2018): 23-50. DOI : 10.21043/libraria.v6i1.2215. 
Hambatan pengembangan karier menurut Krestyawan (2018) bahwa "hambatan utama yang ditemui dalam pengembangan karir, yaitu: kurangnya rasa percaya diri, kebiasaan dan perilaku buruk, kurangnya informasi untuk mengembangkan karir, tujuan karir dan nilai-nilai diri yang tidak selaras, kurangnya kesadaran diri tentang kekuatan-kekuatan diri, pengetahuan, keterampilan diri, ketidakmampuan berkomunikasi secara efektif,dan kurangnya jaringan yang mendukung". ${ }^{8}$ Faktor yang mempengaruhi kenaikan pangkat/jabatan pustakawan dipengaruhi oleh faktor eksternal dan faktor internal. Faktor internal berasal dari dalam diri pustakawan yang bersangkutan, misalnya: minat, motivasi, kesungguhan, persepsi menjadi pustakawan, jenjang pendidikan Perpusdokinfo maupun minat bekerja di perpustakaan. Faktor eksternal berasal dari luar diri pustakawan yang bersangkutan, misalnya: nilai satuan angka kredit dalam butir kegiatan kepustakawanan yang terlampau kecil, lingkungan kerja kurang kondusif, tim penilai yang kurang kompeten dalammelakukan penilaian, perhatian pimpinan terhadap pustakawan kurang mendukung, apresiasi terhadap profesi pustakawan yang sangat kurang darilembaga, pustakawan selain mengerjakan tupoksi juga mengerjakan pekerjaan lain di luar perpusdokinfo.

Berdasasrkan beberapa pendapat di atas, maka dapat dikatakan bahwa ada beberapa faktor penghambat yang menyebabkan kegiatan pengembangan profesi meliputi pengembangan diri, publikasi ilmiah dan karya inovasi antara lain: kurangnya pengetahuan, kemampuan dan keterampilan; rendahnya minat; motivasi pustakawan rendah;tidak percaya diri, tidak fokus, terbatasnya waktu; kurang produktivitas karena faktor lingkungan; terbatasnya anggaran dan wadah; dan kurangnya perhatian dari pimpinan. Sementara itu, hambatan dalam pengembangan karier yaitu minat, motivasi, jenjang pendidikan, prestasi kerja, kurang percaya diri, tidak yakin dengan kompetensi diri, kurangnya informasi, merasa puas dengan jabatan yang dimiliki, nilai satuan angka kredit terlampau kecil, kurangnya jaringan kerjasama. Hambatan-hambatan pengembangan profesi tersebut

\footnotetext{
${ }^{8}$ Rendra Krestiawan, 7 Hambatan Utama dalam Mengembangkan Karir. Artikel Manajemen SDM, 22 Juni 2018, http://manajemen-sdm.com/manajemen-karir.
} 
akan berdampak pada perkembangan karier.

Berdasarkan hal tersebut, maka perlu dilakukan suatu penelitian untuk menjawab permasalahan apakah pengembangan profesi meliputi kegiatan pengembangan diri, publikasi ilmiah, dan karyai novatifberpengaruh terhadap perkembangan karier pustakawan di Universitas Hasanuddin. Penelitian ini bertujuan untuk menganalisis dan mendeskripsikan gambaran tentang pengaruh pengembangan profesi terhadap perkembangan karier pustakawan serta hambatan-hambatan yang dihadapi oleh pustakawan dalam melakukan kegiatan pengembangan profesi dan perkembangan kariernya di Universitas Hasanuddin. Hasil penelitian ini dapat menjadi bahan masukan dan pertimbangan bagi Universitas Hasanuddin Makassar dalam menyusun rencana strategis dan operasional untuk pengembangan profesi jabatan pustakawan; dan bahan perbandingan dan sumber rujukan bagi penelitipeneliti atau penulis yang mengkaji tentang pengembangan profesi dan pengembangan karier jabatan fungsional pustakawan;serta dapat memberikan sumbangsih bagi perkembangan ilmu pengetahuan di bidang kepustakawanan.

\section{TINJAUAN PUSTAKA}

Beberapa hasil penelitian atau pengkajian sebelumnya yang berkaitan dengan pengembangan profesi dan perkembangan karier bagi tenaga fungsional tertentu untuk dapat dijadikan pedoman dalam penelitian ini. Penelitian yang dilakukan oleh Septyanti dkk. (2018) mengatakan bahwa "pengembangan keprofesian berkelanjutan yang diberikan kepada guru pada program pengabdian ini terdiri dari 3 kegiatan yakni pengembangan diri, kegiatan publikasi ilmiah, dan karya inovatif. Melalui kegiatan kepada masyarakat yang diberikan, para guru diharapkan memahami program pemerintah terkait kegiatan $\mathrm{PKB}$ dan dapat mengimplementasikan dalam ruang lingkup kerja. Hal ini juga dapat menunjang angka kredit guru untuk kenaikan pangkat bagi guru se-Kecamatan Bangkinang".

${ }^{9}$ Elvrin Septiyanti, dkk., Penyuluhan Pengembangan Keprofesian Berkelanjutan bagi Guru se-Kecamatan Bangkinang Kabupaten Kampar. Wahana Dedikasi, Vol.1 No. 2(2018). https://garuda. ristekbrin.go.id. 
Menurut Rohmah (2016) bahwa "pelaksanaan program keprofesian berkelanjutan dapat meningkatkan kompetensi pedagogik, profesional, sosial dan kepribadian untuk memenuhi kebutuhan dan tututan masa depan yang berkaitan dengan profesi sebagai guru. Peningkatan kompetensi tersebut dapat menunjang layanan pendidikan bermutu dan berimplikasi pada perolehan angka kredit untuk pengembangan karir guru. Unsur pengembangan keprofesian berkelanjutan berupa pengembangan diri, publikasi ilmiah, dan karya inovatif diharapkan dapat dilakukan secara teratur, sistematis, dan berkelanjutan sesuai dengan kebutuhan pengembangan profesinya. Angka kredit yang dicapai dalam unsur pengembangan keprofesian berkelanjutan dapat mendukung pengembangan karif guru yang lebih obyektif, transparan, dan akuntabel. Sehingga dapat mendorong pengakuan profesi guru sebagai lapangan pekerjaan bermartabat dan bermakna bagi masyarakat dalam mencerdaskan kehidupan bangsa". 10

Hasil penelitian oleh Novianto (2020) mengatahan bahwa "pelaksanaan kegiatan pengembangan profesi, dalam hal ini penulisan karya ilmiah dapat memberikan kontribusi yang cukup signifikan dalam pengembangan karir pustakawan. Terdapat beberapa keuntungan bagi pustakawan ketika melaksanakan kegiatan pengembangan profesi, yaitu (1) angka kredit kegiatan pengembangan profesi cukup besar, dan (2) butir-butir kegiatan pengembangan profesi dapat dilaksanakan oleh semua jenjang jabatan pustakawan. Kegiatan pengembangan profesi dapat membantu pustakawan dalam mengumpulkan angka kredit untuk kenaikan jabatan/ pangkat, karena tidak jarang terjadi pustakawan yang kesulitan mencari angka kredit dari kegiatan sehari-hari karena tempat ia bertugas tidak mampu mengakomodirbutir-butir kegiatan dalam Permenpan-RB Nomor 9Tahun 2014 sesuai jenjang jabatannya". ${ }^{11}$ Selanjutnya hasil penelitian Julianto (2018) bahwa "ada banyak kendala dan hambatan dalam melakukan publikasi

\footnotetext{
${ }^{10}$ Wafrotur Rohmah, Upaya Meningkatkan Pengembangan Keprofesian Berkelanjutan Dalam Peningkatan Profesionalisme Guru. Makalah Seminar Nasional Pendidikan, (2016): 1-21.

${ }^{11}$ Achmad Qorni Novianto, Publikasi ilmiah pustakawan: kontribusinya pada citra profesi, pengembangan karir dan transformasi ilmu pengetahuan. Jurnal Almaktabah, Vol.5, No. 1(2020): 59-74. DOI: 10.29300/mkt.v5i1.2877.
} 
di prodi psikologi UIN Sunan Kalijaga. Kendala tersebut bermuara dari ketidakpahaman subjek penelitian terhadap pemanfaatan teknologi untuk melakukan publikasi". ${ }^{12}$

Hasil penelitian tentang pengembangan karier pustakawan yang dilakukan oleh Ariomerebi dan Ifeakachuku (2013) mengatakan bahwa "ada hubungan antara minat profesi, motivasi untuk pengembangan profesi dan komitmen untuk karir yang berujung pada pengembangan karir. Mayoritas pustakawan Nigeria tidak pernah tertarik pada profesi pustakawan sebelum masuk, hanya mempelajarinya. Namun, pilihan terakhir bagi mereka pada saat itu dan beberapa mengambilnya dengan tujuan untuk beralih ke profesi lain. Meskipun mereka yakin bahwa kepustakawanan sama baiknya dengan profesi lain sepertiKedokteran dan Hukum, sehingga memiliki minat besar demi pengembangankariernya. Pustakawan wanita tampaknya tidak memilih profesi pustakawan sebagai hal yang penting. Peluang dan upaya peningkatan kapasitas pustakawan wanita sangatrendah dan orang bertanyatanya dampaknya terhadap pengembangan karir mereka. Berbagai hambatan yang dihadapi oleh pustakawan wanita Nigeria dalam pengembangan profesi khususnya di bidang pelatihan". ${ }^{13}$ Menurut Igere et al. (2020) bahwa "motivasi kerja untuk pustakawan secara signifikan memprediksi komitmen karir. Oleh karena itu, motivasi kerjaharus didorong di perpustakaan universitas". ${ }^{14}$

\subsection{Perkembangan Profesi Pustakawan}

Pustakawan sebagai tenaga profesional memiliki motivasi dan semangat tinggi untuk meningkatkan pengembangan profesi dalam berbagai kegiatan pengembangan profesi. Pengembangan profesi adalah pengembangan pengetahuan, keahlian, keterampilan, sikap dan bakat

${ }^{12}$ Very Julianto, Faktor-Faktor Penghambat Meningkatnya Kemampuan Publikasi di Program Studi Psikologi UIN Sunan Kalijaga Yogyakarta. Jurnal Psikologi Integratif, Vol.6, No. 2 (2018): 131-140

${ }^{13}$ Ariomerebi, et al, Interest and Self Motivation as Correlates Capacity Building and Career Comitment: a Study of Librarians in Nigeria. Brazilian Journal of Information Science: Research Trends, Vol.7, No. 2(2013): 29-46, https://www.proquest.com.

${ }^{14}$ Mercy Arodovwe Igere et al., The predictive nature of work motivation and career commitment of librarians in Universities in Southern Nigeria. Library Philosophy and Practice; Lincoln (2020): 1-24, https://www.proquest.com. 
yang bermanfaat untuk profesi pustakawan dalam melaksanakan tugas kepustakawanan. Pustakawan adalah Pegawai Negeri Sipil (PNS) yang diberi tugas, tanggung jawab, wewenang dan hak untuk melaksanakan kegiatan kepustakawanan. ${ }^{15}$ Pengetahuan pustakawan turut menentukan berhasil tidaknya pelaksanaan tugas dan tanggungjawab yang dibebankan kepadanya, pengetahuan merujuk pada informasi dan hasil pembelajaran. Pengembangan profesi adalah pengembangan pengetahuan, keahlian, keterampilan, sikap dan bakat yang bermanfaat untuk profesi dalam melaksanakan tugasnya. Tujuan pengembangan profesi pustakawan adalah untuk mengembangkan dan meningkatkan kompetensi dalam melaksanakan kegiatan di bidang kepustakawanan, meningkatkan citra dan karier serta prestasi pustakawan. Dengan demikian, pengembangan profesi pustakawan itu sangat penting dalam rangka menghadapi perkembangan ilmu pengetahuan dan teknologi informasi.

Menurut Ismanto (2019) bahwa "dasar pertinbangan pengembangan profesi, sebagai berikut: Pertama, bahwa tugas, peran dan fungsi pustakawan dari waktu ke waktu selalu mengalami peningkatan, pembaharuan dan perkembangan. Oleh sebab itu, kemampuan mereka harus terus dikembangkan sesuai dengan tuntutan jaman. Kedua, bahwa seorang pustakawan adalah sebagai perancang masa depan dalam menyediakan informasi bagi penggunanya. Sebagai perancang yang professional maka tenaga yang ada di perpustakaan termasuk didalamnya pustakawan sebagai penyedia informasi harus terus dikembangkan kemampuannya sehingga lebih berkualitas dalam mengembangkan ide-ide yang inovatif. Ketiga, bahwa pengembangan profesi kepustakawanan adalah normatif, historis, filosofi dan sosiologi. Dasar normative adalah dasar yang diambil dari kitab suci dan dari peraturan perundang-undangan yang relevan. Sedangkan dasar historis adalah dasar yang diambil dari pengalaman sejarah di masa lalu. Sedangkan dasar filosofis adalah dasar yang diambil dari falsafah, hikmah dan ajaran yang dibutuhkan. Dasar sosiologis adalah dasar yang diambil dari keadaan masyarakat pengguna perpustakaan sekarang". ${ }^{16}$

\footnotetext{
${ }^{15}$ Permenpan RB RI Nomor 9 Tahun 2014, Op.Cit., hal 5.

${ }^{16}$ Ismanto, Pengembangan Profesi Pustakawan Menuju Kinerja Profesional. Perpustakaan
} 
Kegiatan pengembangan profesi meliputi kegiatan pengembangan diri, publikasi ilmiah dan karya inovatifmerupakan pelaksanaan program keprofesian dengan harapan dapat menciptakan pustakawan yang professional dengan kemampuaan IPTEK dan kepribadian yang handal. Pelaksanaan program tersebut, dapat meningkatkan kompetensi kepustakawanan, profesional, sosial dan kepribadian untuk memenuhi kebutuhan dan tututan masa depan yang berkaitan dengan profesi pustakawan. Peningkatan kompetensi tersebut, dapat menunjang layanan perpustakaan yang berkualitas, dan berimplikasi pada perolehan angka kredit untuk perkembangan karir pustakawan.

"Pengembangan diri adalah suatu proses pembentukan potensi, bakat, sikap, perilaku dan kepribadian seseorang melalui pembelajaran dan pengalaman yang dilakukan berulang-ulang sehingga meningkatkan kapasitas atau kemampuan diri sampai pada tahap kemandirian" (Riadi, 2014)". ${ }^{17}$ Kegiatan pengembangan diri pustakawan adalah upaya-upaya yang dilakukan oleh pustakawan dalam rangkan meningkatkan profesinalismenya. Tujuan pengembangan diri pustakawan yaitu untuk memaksimalkan segala potensi yang dimiliki pustakawan, sehingga mampu mengikuti tuntutan perubahan terknologi informasidan komunikasi serta perkembangan ilmu pengetahuan. Melalui kegiatan pengembangan diri, pustakawan dapat memiliki kompetensi yang sesuai dengan undang-undang dan peraturanperaturan yang mengatur dengan harapan pustakawan dapat melaksanakan tugas dan fungsinya sebagai pengelola perpustakaan. Tugas dan fungsi pustakawan adalah mencari, menhimpun, mengolah, melayankan dan menyebarluaskan informasi yang ada di perpustakaan guna memenuhi kebutuhan penggunanya. Sejalan dengan pendapat Septyanti, dkk. (2018) mengatakan "bahwa kegiatan pengembangan diri adalah upaya untuk meningkatkan profesionalisme diri agar memiliki kompetensi yang sesuai dengan peraturan perundang-undangan atau kebijakan pendidikan nasional Universitas Islam Indonesia. Buletin Perpustakaan Universitas Islam Indonesia, Vol.2, No. 2(2019): 151-160, https://journal.uii.ac.id/Buletin-Perpustakaan/article/ view/15188/10086.

${ }^{17}$ Muchlisin Riadi, Pengembangan Diri (Pengertian, Tujuan, Fungsi, Bentuk dan Pelaksanaan). Kajian Pustaka Com, 28 Juni 2020. 
serta perkembangan ilmu pengetahuan, teknologi dan/atau seni. Kegiatan tersebut dilakukan melalui pendidikan dan pelatihan (diklat) fungsional, teknis dan/atau melalui kegiatan kolektif guru". ${ }^{18}$

Publikasi ilmiahadalah kegiatan penyebarluasan suatu hasil penelitian atau pengkajian ilmiah yang dilakukan oleh seseoran atau kelompok. Tujuan pulikasi ilmiah adalah untuk memberikan informasi kepada pembaca tentang karya ilmiah yang telah dihasilkan. Menurut Indrastuti (2018) bahwa "karya tulis ilmiah merupakan suatu karya tulis yang berisi analisis suatu hal yang empiris (dapat dibuktikan) dan analisis tentang data nyata yang didasari oleh teori yang relevan dan dilakukan dengan metode atau prosedur ilmiah". ${ }^{19}$ Selanjutnya hasil penelitian Novianto (2020) mengatakan bahwa "menulis karya tulis ilmiah merupakan salah satu upaya pemasaran kepada publik mengenai berbagai hal yang terkait dalam sebuah profesi, tak terkecuali pustakawan. Melalui tulisan karya ilmiah yang dipublikasikan secara luas berupa buku, artikel jurnal ilmiah maupun media massa, pustakawan dapat membuktikan eksistensi pustakawan dan upaya meningkatkan profesionalisme pustakawan dalam dunia akademik" . ${ }^{20}$ Sementara itu, pendapat Mukhadis (2017:12) bahwa "suatu karya tulis dikatakan ilmiah jika memiliki kebenaran dari sisi substansi isi secara metodologis dan kemasan paparannya secara umum memiliki kedelapan ciri berikut: 1) menggunakan bahasa prosa, bukan bahasa puisi; 2) menggunakan pola kalimat bentuk lampau; 3) menggunakan pola kalimat bentuk pasif; 4) taat terhadap konvensi; 5) menggunakan format penulisan tertentu; 6) menggunakan bahasa yang benar dan baku; 7) menyajikan persoalan penting; 8) disajikan secara sistematis objektif". ${ }^{21}$

Kontribusi pustakawan dalam kegiatan publikasi ilmiah di bidang kepustakawanan merupakan salah satu upaya pembuktian bahwa pustakawan mampu membuat suatu karya ilmiah dan dapat disejajarkan dengan profesi

\footnotetext{
${ }^{18}$ Septiyanti, Op.Cit, hal. 12.

${ }^{19}$ Novi Indrastuti, Cara praktis penulisan karya ilmiah dalam Bahasa Indonesia. (Yogyakarta: Gadjah Mada University Press, 2018).

${ }^{20}$ Novianto, Op.Cit, hal. 72.

${ }^{21}$ A Mukhadis, Kiat Menulis Karya Ilmiah: Bentuk, Anatomi, Isi Esensial, dan Contoh Aplikasinya. (Malang: Aditya Media Publishing, 2017), hal. 12.
} 
lainnya. Pustakawan dapat membangun citra profesionalisme melalui kegiatan bidang kepenulisan. Sementara kontribusinya untuk pengembangan karier pustakawan, karya ilmiah merupakan unsur utama kegiatan pustakawan yang dinilai point kreditnya. Salah satu aspek pengembangan profesi adalah kegiatan karya tulis ilmiah merupakan syarat mutlak bagi pustakawan ahli untuk naik kejenjang jabatan lebih atas. Sebagai mana telah di jelaskan dalam Kepala Perpustakaan Nasional Republik Indonesia Nomor 11 Tahun 2015 tentang Petunjuk Teknis Jabatan Fungsional Pustakawan dan Angka Kreditnya, "terdapat unsur pengembangan profesi yang merupakan unsur utama kegiatan kepustakawanan dan unsur kegiatan yang mengakomodasi berbagai macam jenis karya ilmiah yang dapat dihasilkan oleh pustakawan".22

Perpustakaan merupakan sarana belajar sepanjang hayat yang mampu mengembangkan potensi masyarakat menjadi manusia berilmu, mandiri, kreatif dan inovatif. Perpustakaan mampu menjadi agen perubahan, khususnya dalam dunia pendidikan. "Perpustakaan sebagai agen perubahan tentunya memiliki sumber daya manusia yang kompeten, berkualitas, kreatif, dan inovatif. Pustakawan yang kompoten adalah pustakawan yang memiliki kemampuan, sikap, pengetahuan, keterampilan yang diperoleh melalui pendidikan atau pelatihan kepustakawanan. Pustakawan berkualitas adalah pustakawan yang memiliki ideologi yang kuat, kualitas pengetahuan dan keterampilan yang baik, serta memiliki semangat perintis inovasi. Pustakawan kreatif adalah pustakawan yang mampu menciptakan gagasan dan metode baru dalam rangka menarik dan menumbuhkan minat masyarakat untuk memanfaatkan perpustakaan (Istiana, 2017)". ${ }^{23}$ Sementara, pustakawan inovatif adalah pustakawan yang selalu ingin belajar, giat bekerja, kaya dengan gagasan-gagasan baru, berorientsi kedepan, berpikir rasional, memiliki sikap dan perilaku yang baik, dan selalu melakukan penelitianpenelitian kepustakawanan.

${ }^{22}$ Peraturan Kepala Perpustakaan Nasional Republik Indonesia Nomor 11 Tahun 2015, Op.Cit, hal. 33 .

${ }^{23}$ Purwani Istiana, Pustakawan Berkualitas Tinggi: Urgensi Perpustakaan Perguruan Tinggi sebagai “fountain of Knowledge". Jurnal Ilmu Perpustakaan dan Informasi, Vol.2, No. 1(2017): 107-114. DOI : 10.30829/jipi.v2i1.924 


\begin{abstract}
"Inovasi pustakawan sebagai agen perubahan dalam mengembangkan perpustakaan di era informasi dengan berinovasi melalui layanan kreatif, inovasi layanan pemustaka, inovasi penataan ruang, dan inovasi pembelajaran yang kolaboratif dan inspiratif dan harus mempunyai ide dalam berinovasi agar memiliki sesuatu yang baru dalam melayani pemustaka. Sebagai agen perubahan pustakawan harus unggul dalam memberikan pendampingan, melayani, dan memberikan konsultasi informasi dan pengetahuan kepada pemustaka (Syahril, 2019)"..2 Pengembangan profesi pustakawan melalui karya inovatif merupakan suatu kegiatan yang penting dalam perpustakaan. Tujuan pengembangan karya inovatif adalah untuk meningkatkan pengetahuan dan keterampilan pustakawan dalam berinovasi baik dibidang pengelolaan perpustakaan maupun penyusunan standar, pedoman serta pengemasan berbagai jenis informasi. "Karya inovatif adalah karya yang bersifat pengembangan, modifikasi atau penemuan baru sebagai bentuk kontribusi guru terhadap peningkatan kualitas proses pembelajaran di sekolah dan pengembangan dunia pendidikan, sains/teknologi, dan seni. Karya inovatif ini dapat berupa penemuan teknologi tepat guna, penemuan/ penciptaan atau pengembangan karya seni, pembuatan/modifikasi alat pelajaran/ peraga/praktikum, atau penyusunan standar, pedoman, soal, dan sejenisnya pada tingkat nasional maupun provinsi (Septyanti, 2018)".25
\end{abstract}

\title{
2.2. Perkembangan Karier Pustakawan
}

Pustakawan merupakan jabatan fungsional dan sebuah karier dalam organisiasi perpustakaan yang sudah diatur oleh pemerintah melalui peraturan perundang-undangan. Dalam peraturan pemerintah tersebut, pengembangan karir jabatan fungsional pustakawan cukup jelas dalam proses kenaikan jabatannya. Menurut Lasa dalam Fitriani (2013) menjelaskan bahwa "jabatan fungsional pustakawan adalah jabatan karier pada unit perpustakaan, dokumentasi, dan informasi yang hanya dapat diduduki oleh seseorang yang memiliki minimal pendidikan di bidang pusdokinfo dan diangkat sebagai pegawai negeri sipil atau pegawai tetap perpustakaan". Oleh karena itu, jabatan fungsional pustakawan merupakan karir yang

${ }^{24}$ Syahrir, Innovation Librarian as a Agent of Change in Developing Library in Era Information. Al Maktabah Jurnal kajian Ilmu dan Perpustakaan, Vol. 4, No. 2(2019), DOI: 10.29300/ mkt.v4i2.2519

${ }^{25}$ Septiyanti, Op.Cit., hal. 
perlu dikembangkan. Adapun jenjang karir atau jabatan pustakawan diatur dalam Peraturan Menteri Pendayagunaan Aparatur Negara dan Reformasi Birokrasi RI Nomor 9 Tahun 2014 tentang Jabatan Fungsional Pustakawan dan Angka Kreditnya terdiri atas : a) Pustakawan Tingkat Terampil yaitu "pustakawan pelaksana, pustakawan pelaksana lanjutan dan pustakawan penyelia; ) Pustakawan Tingkat Ahli, yaitu pustakawan pertama, pustakawan muda, pustakawan madya, dan pustakawan". ${ }^{26}$

Pengembangan karir pustakawan adalah suatu proses perjalanan pekerjaan yang dilakukan oleh pustakawan dalam rangka melakukan suatu perubahan status, jabatan, posisi atau kedudukan yang telah direncanakan. Menurut Siagian (2015:68) bahwa "pengembangan karir adalah perubahanpribadi yang dilakukan seseorang untuk mencapai suatu rencana karir" ${ }^{27}$ Sejalan dengan pendapat Widodo (2015:53) mengatakan "pengembangan karir adalah serangkaian aktivitas sepanjang hidup yang berkontribusi pada eksplorasi, pemantapan, keberhasilan dan pemenuhan karir seseorang" ${ }^{28}$ Kedua pendapat tersebut dikatakan bahwa pengembangan karir merupakan seseorang yang bekerja pada suatu organisasi melakukan serangkaian kegiatan pengembangan diri dalam rangka mencapai keberhasilan jenjang karir yang diinginkan dan direncanakan.

Menurut Zulbahri (2020) bahwa "pengembangan karier menunjukkan pada perkembangan secara individu dalam jenjang kepangkatan dan jabatan yang dapat dicapai selama masa tertentu dalam suatu organisasi atau perusahaan. Pengembangan karier tiap karyawan tentu antara satu dengan yang lainnya tidak sama karena banyak faktor yang mempengaruhinya. Dimana keberhasilan karier individu dipengaruhi oleh fakor-faktor seperti: pendidikan formal, pengalaman kerja, sikap atasan, pestasi kerja, bobot

${ }^{26}$ Peraturan Menteri Pendayagunaan Aparatur Negara dan Reformasi Birokrasi Republik Indonesia Nomor 9 Tahun 2014, Op.Cit., hal. 11.

${ }^{27}$ Sondang P Siagian, Manajemen Stratejik. (Jakarta: Bumi Aksara, 2012).

${ }^{28}$ Zulbahri, Pengaruh Pengeambangan Karir dan Disiplin Kerja terhadap Kepuasan Kerja dan Kinerja ASN Studi Kasus di SMK 2 Kota Bima (Suatu Kajian Studi Literatur Manajemen Sumber Daya Manusia). Jurnal Manajemen Pendidikan dan Ilmu Sosial, Vol. 1, No. 2(2020): 622-642. DOI: 10.38035/jmpis.v1i2.398 
pekerjaan, lowongan jabatan dan produktivitas kerja". "Pengembangan karier pustakawan meliputi pembinaan yang mengarah pada pencapaian jenjang jabatan dan pangkat tertinggi, dimana setiap kenaikan pangkat dan golongan didasarkan pada pengumpulan angka kredit kumulatif yang diperoleh pustakawan yang bersangkutan, yang meliputi : (1) unsur utama $>80 \%$ ),yangterdiri dari pendidikan; pengorganisasian danpendayagunaan koleksi bahan pustaka/sumber informasi; pemasyarakatan perpustakaan, dokumentasidan informasi; pengembangan profesi dan (2) unsur penunjang $<20 \%)^{\text {" }}{ }^{30}$

Penelitian ini relatif berbeda dengan penelitian terdahulu yang telah disebutkan di atas. Meskipun sama-sama mengkaji tentang pengembangan profesi dan perkembangan karier pustakawan di Perguruan Tinggi. Penelitian terdahulu mengkaji tentang sarana dan tujuan dari pengembanga profesi dan perkembangan karier pustakawan, sementara penelitian ini mengkaji tentang kegiatannya. Penelitian ini mengevaluasi indikator-indikator kegiatan pengembangan profesi dan perkembangan karier pustakawan di Universitas Hasanuddin, dan hambatan-hambatan apa yang dihadapi dalam melaksanakan kegiatan tersebut.

\subsection{Hambatan-Hambatan dalam Pengembangan Profesi dan Pengembangan Karier Pustakawan}

\subsubsection{Hambatan Pengembangan Profesi}

Pengembangan profesionalisme pustakawan harus terus ditingkatkan karena merupakan suatu hal yang amat penting dan harus dimiliki oleh para pustakawan.Keberadaan pustakawan senantiasa memberikan makna profesional. Karena profesionalisme akan melahirkan sikap terbaik bagi seorang pustakawan dalam melayani pemustaka. Sikap ini nantinya tidak saja berguna dalam melayani pemustaka, tetapi juga berguna bagi

${ }^{29}$ Zulbahri, Pengaruh Pengeambangan Karir dan Disiplin Kerja terhadap Kepuasan Kerja dan Kinerja ASN Studi Kasus di SMK 2 Kota Bima (Suatu Kajian Studi Literatur Manajemen Sumber Daya Manusia). Jurnal Manajemen Pendidikan dan Ilmu Sosial, Vol. 1, No. 2(2020): 622-642. DOI: 10.38035/jmpis.v1i2.398.

${ }^{30}$ Permenpan RB RI Nomor 9 Tahun 2014, Op.Cit., hal. 27 
masyarakat umum dan institusi tempat pustakawan bekerja. Pengembangan profesi bagi pustakawan sangatlah penting dalam rangka meningkatkan kompetensi, kualitas kerja, kinerja dan karier pustakawan. Namun kegiatan pengembangan profesi seperti pengembangan diri, publikasi ilmiah dan karya inovatif berbagai hambatan yang dihadapi oleh pustakawan.

Menurut Suprianto (2015) mengatakan "bahwa ada dua faktor penghambat dalam pengembangan profesionalisme guru yaitu faktor internal dan faktor ekternal. Faktor internal antara lain: 1) minat untuk melaksanakan pengembangan dan kemampuan menulis guru; 2) keterbatasan waktu yang disebabkan oleh beban tugas selain tugas-tugas; 3) kualifikasi dan latar belakang pendidikan tidak sesuai dengan bidang tugas, kompetensi yang diperlukan belum mendukung dengan tugas-tugas pokok guru, penghasilan tidak sesuai dengan prestasi kerja, kurangnya kesempatan untuk mengembangkan profesi secara berkelanjutan disebabkanoleh aktivitas guru yang justru terjebak pada rutinitas, tidak adanya upaya pihak berwenang untuk mendorong guru ke arah pengembangan kompetensi diri ataupun karier, guru kurang termotivasi untuk melakukan pengembangan profesionalisme dan tergerak secara pribadi untuk mengembangkan profesinya, kebiasaan penggunaan cara mengajar yang dilakukan secara monoton dan ketrampilan guru dalam melaksanakan pengembangan profesi masih rendah. Faktor eksternal adalah guru tidak memiliki latar belakang pengetahuan dan ketrampilan yang kuat tentang pengembangan profesi, lingkungan kerja guru yang kurang mendukung kegiatan-kegiatan pengembangan, PGRI belum berperan secara aktif dalam pengembangan profesi guru" ${ }^{31}$

Lebih lanjut Suryantini (2015) mengatakan "bahwa hambatan teknis pustakawan dalam menulis KTI adalah kurang menguasai metodologi pengkajian, kurang penguasaan teknik penulisan ilmiah, kurang pengalaman menulis KTI, sulit menemukan topik, dan kurang mampu berpikir kritis. Faktor nonteknis yang menghambat pustakawan dalam menulis KTI yaitu

${ }^{31}$ Sapto Edy Suprianto, Analisis Pengembangan Profesional Guru Berkelanjutan di SMK Negeri 2 Sragen. Artikel Publikasi Institutional Repository UMS, 2015. http://eprints.ums.ac.id/40951/1/ ARTIKEL\%20PUBLIKASI. 
sibuk dengan tugas selain sebagai pustakawan, kurang tersedia panduan penulisan, dan tidak ada sanksi jika tidak menulis KTI". ${ }^{32}$ Sejalan dengan hasil penelitian Julianto (2018) mengatakan bahwa hambatan-hambatan publikasi pada dosen dan mahasiswa prodi Psikologi UIN Sunan Kalijaga disebabkan oleh: 1) kurangnya kemampuan dalam menulis; 2) kurangnya kemampuan dalam menggunakan teknologi; 3) kurangnya kemampuan berbahasa; 4) kurangnya pengetahuan mengenai adanya sumber-sumber referensi online tersebut dan cara mengaksesnya". ${ }^{33}$ Sementara itu, Zuhri (2014) mengatakan bahwa Karya inovatif adalah karya yang bersifat pengembangan, modifikasi atau penemuan baru sebagi bentuk kontribusi guru terhadap peningkatan kualitas proses pembelajaran di sekolah. Karya inovatif ini dapat berupa penemuan teknologi tepat guna, pengembangan karya seni, pembuatan atau modifikasi alat pelajaran".34

\subsubsection{Hambatan Pengembangan Karier}

Karir adalah merupakan jabatan atau posisi yang di dapatkan oleh seseorang pada sebuah organisasi. Sedangkan jabatan adalah kedudukan yang menunjukkan tugas, tanggung jawab, wewenang, dan hak seorang pegawai dalam suatu organisasi. Karir dapat mempengaruhi kehidupan seseorang. Untuk itu seseorang mempunyai hak yang sama dalam mengembangkan karirnya sesuai dengan kompetensi yang dimiliki. "Pengembangan karier yang efektif akan memperbaiki dan meningkatkan efektifitas pelaksanaan pekerjaan oleh pegawai, agar semakin mampu memberikan kontribusi terbaik dalam mewujudkan tujuan organisasi dengan lingkungan yang selalu berubah (Kadarisman, 2018)". ${ }^{35}$ Pengembangan karir bagi pegawai dalam sebuah organisasi baik pemerintah maupun swasta sangat

${ }^{32}$ Heryati Suryantini dan Endang Setyorini, Hambatan Pustakawan Dalam Penulisan Karya Ilmiah Untuk Jurnal Perpustakaan Pertanian. JurnalPustakawanPertanian, Vol.24 No. 2(2015): 59-68.

${ }^{33}$ Very Julianto, Faktor-Faktor Penghambat Meningkatnya Kemampuan Publikasi di Program Studi Psikologi UIN Sunan Kalijaga Yogyakarta. Jurnal Psikologi Integratif, Vol.6, No. 2(2018): 131-140

${ }^{34}$ Muhammad Minan Zuhri, Pengembangan Sumber Daya Guru dan Karyawan Dalam Organisiasi. Quality: Jurnal of Empirical Research in Islamic Education, Vol,2, No. 2(2014): 205-221

${ }^{35}$ Muh. Kadarisman, Analisis Pengembangan Karier Aparatur Sipil Negara di Pemerintahan Kota Depok. E-Journal BKN, Vol. 12, N. 2(2018): 115-138. 
penting, karena karir merupakan kebutuhan yang harus dikembangkan dalam diri seorang pegawai agar dapat memotivasi untuk meningkatkan produktivitas dan kinerjanya. Namun, dalam pengembangan karier karier seorang pegawai menghadapi berbagai kendala atau hambatan baik dari dalam maupun dari luar pegawai.

Hambatan pustakawan dalam pengembangan karier sering menjadi suatu persoalan yang tidak disadari. Banyak pustakawan mengeluh karirnya yang tidak beranjak lebih baik dengan menyalahkan kondisi lingkungan, seperti penempatan, peraturan yang mengikat, dan lain-lain. Beberapa hambatan utama yang ditemui dalam pengembangan karir sebagai berikut: kurangnya rasa percaya diri; kebiasaan dan perilaku buruk; kurangnya informasi untuk mengembangkan karir; Tujuan karir dan nilai-nilai diri yang tidak selaras; kurangnya kekuatandiri, pengetahuan, keterampilan; tidakmampuan berkomunikasi becara efektif; kurangnya Jaringan yang mendukung. Menurut Siagian (2012) mengatakan bahwa "faktor yang mempengaruhi pengembangan karir adalah sebagai berikut: 1) Perlakuan yang adil dalam berkarir; 2) Keperdulian para atasan langsung Para karyawan pada umumnya mendambakan keterlibatan atasan langsung mereka dalam perencanaan karir masing-masing. 3) Informasi tentang berbagai peluang promosi; 4) Minat untuk dipromosikan; 5) Tingkat kepuasaan". ${ }^{36}$ "pengembangan karier pegawai pada Kantor Dinas Pendapatan Daerah Provinsi Sulawesi Tengah belum maksimal, karena adanya faktor perlakuan adil, kepedulian , promosi, dan tingkat kepuasan belum maksimal. Sementara itu, faktor minat sudah maksimal (Muhajir, 2015)".37

\section{METODE PENELITIAN}

Penelitian ini menggunakan pendekatan kuantitaif dengan metode survei yaitu penelitian yang menggunakan kuesioner atau angket.

${ }^{36}$ Sondang P. Siagian, Manajemen Stratejik. (Jakarta: BumiAksara, 2012).

${ }^{37}$ Muhammad Muhajir, Analisis Pengembangan Karir Pegawai pada kantor Dina Pendapatan Daerah Provinsi Sulawesi Tengah. e-Jurnal Katalogis, Vol.3, No. 12(2015): 142-149. https://media. neliti.com/media 
Populasi penelitian adalah semua pegawai perpustakaan Universitas Hasanuddin sebanyak 57 orang (data statistic, 2020). Sampel penelitian adalah pustakawanpegawai negeri sipil Universitas Hasanuddin. Pemilihan sampel dilakukan dengan menggunakan metode purposive sampling, teknik penentuan sampel dengan pertimbangan tertentu. Jumlah sampel sebanyak 48 pustakawan Pegawai. Metode pengumpulan data menggunakan angket atau kuesioner dan dokumentasi. Pengolahan data menggunakan SPSS 25.0. Metode analisis data adalah statistik deskriptif dan analisis regresi linear berganda. Untuk pengujian data dilakukan uji parsial atau sendirisendiri (T-Tes) yaitu untuk menganalisis pengaruh masing-masing variable independen $(\mathrm{X})$ terhadap variable dependen $(\mathrm{Y})$ dengan asumsi bahwa bila nilai $\mathrm{T}$ hitung lebih besar dari $\mathrm{T}$ tabel, maka Ho ditolak, artinya signifikan. Sebaliknya jika T hitung lebih kecil dari nilai T tabel, maka Ho diterima, artinya tidak signifikan. Sementara, uji simultan atau uji bersama-sama (F-Test) yaituuntuk menganalisis pengaruh semua variable independen (X) terhadap variable dependen (Y) dengan asumsi bahwa jika nilai F Hitung lebih besar dari F tabel, maka Ho ditolak, artinya signifikan. Sebaliknya jika nilai F hitung lebih kecil dari nilai F tabel, maka Ho diterima, artinya tidak signifikan. Sementara itu, Uji analisis determinsasi (R2) yaitu untuk menguji besarnya tingkat pengaruh variabel pengembangan profesi pustakawan terhadap variabel perkembangan karier pustakawan.

\section{HASIL DAN PEMBAHASAN}

\subsection{Pengaruh masing-masing Pengembangan Diri, Publikasi Ilmiah, dan Karya Inovatif Terhadap Perkembangan Karier Pustakawan di Universitas Hasanuddin.}

Untuk melihat hasil penelitian pengaruh secara parsial pengembangan profesi pustakawan (Pengembangan Diri, Publikasi Ilmiah, dan Karya Inovatif) terhadap perkembangan karier pustakawan di Universitas Hasanuddin Makassar dapat dilihat pada tabel 1. 
Coefficients $^{\mathrm{a}}$

\section{Tabel 1. Uji Hipotesis Parsial}

\begin{tabular}{clcccc}
\hline Simbol & Variabel Penelitian & Nilai $\mathrm{T}_{\text {hitung }}$ & Nila $\mathrm{T}_{\text {tabel }}$ & $\begin{array}{c}\text { Nilai } \\
\text { Sig. }\end{array}$ & $\begin{array}{c}\text { Nilai Standardized } \\
\text { Coefficients }\end{array}$ \\
\hline $\mathrm{X} 1$ & Kegiatan Pengembangan Diri & 1,705 & 2,021 & 0,095 & 0,230 \\
\hline $\mathrm{X} 2$ & Kegiatan Pubilkasi Ilmiah & $-0,120$ & 2,021 & 0,905 & $-0,018$ \\
\hline $\mathrm{X} 3$ & Kegiatan Karya Inovasi & 3,128 & 2,021 & $, 0,003$ & 0,450 \\
\hline
\end{tabular}

Sumber: data primer, 2021a. Dependent Variable: Perkembangan Karier

Berdasarkan tabel 1, terlihat bahwa variabel kegiatan pengembangan diri pustakawan memiliki nilai $\mathrm{T}_{\text {hitung }}$ sebesar 1,705 dan $\mathrm{T}_{\text {tabel }}$ 2,021. Data tersebut menunjukkan bahwa nilai $\mathrm{T}_{\text {hitung }} 1,705<\mathrm{T}_{\text {tabel }} 2,021$ atau nilai signifikasi0,095 > 0,05, maka Ho diterima. Artinya tidak terdapat pengaruh pengembangan diri terhadap perkembangan karier pustakawan di Universitas Hasanunddin. Besar tingkat tidak signifikansinya yaitu sebesar 0,23 atau $23 \%$. Hasil ini menggambarkan bahwa ternyata kegiatan pengembangan diri pustakawan seperti mengikuti pendidikan lebih tinggi di bidang perpusdokinfo; mengikuti pelatihan atau diklat; mengikuti workshop, seminar, ceramah dan lain-lain; aktif dalam pengurus dan kegiatan Ikatan Pustakawan Indonesia baik lokal maupun nasional tidak memberikan dampakpositif pada perkembangan karier pustakawan di Universitas Hasanudddin.

Pengembangan diri merupakan bentuk perwujudan dari aktualisasi diri, yaitu proses mewujudkan diri menjadi yang terbaik sejalan dengan potensi dan kemampuan yang dimiliki. Setiap individu mempunyai kekuatan yang bersumber dari dirinya, namun banyak orang yang merasa tidak mempunyai kemampuan apa-apa, merasa dirinya tidak berguna dan tidak mampu mencapai aktualisasi diri. Pengembangan bisa dikatakan suatu langkah awal yang dilakukan seseorang guna mengenali dirinya sendiri, dalam segala hal baik itu dalam segi pelajaran, pekerjaan dan lain sebagainya. Sehingga pengembangan diri merupakan suatu proses mengembangkan bakat ataupun potensi yang dimiliki oleh seseorang. "Pengembangan diri 
bisa dilakukan dengan berbagai cara dan berbagai tempat, dalam dunia pendidikan pengembangan diri sendiri termasuk di luar mata pelajaran yang tercantum dalam kurikulum di suatu sekolah. Pengembangan diri merupakan penyesuaian potensi, bakat dan minat seseorang yang merujuk pada definisi diatas pengembangan diri dilakukan dengan berbagai kegiatan dan acara. Kegiatan itu dilakukan untuk menumbuhkan dan semakin memupuk kiranya bakat ataupun potensi apa yang melekat pada seseorang (Antika dan Suharso 2013)" 38

Sementara itu, variabel kegiatan publikasi ilmiah pustakawan pada table 1, diketahui bahwa nilai $\mathrm{T}_{\text {hitung }}$ publikasi ilmiah yaitu sebesar $-0,120$, sedangkan nila $\mathrm{T}_{\text {tabel }}$ yaitu sebesar 2,021. Data tersebut menunjukkan bahwa nilai $\mathrm{T}_{\text {hitung }}-0,120<\mathrm{T}_{\text {tabel }} 2,021$ atau nilai signifikasi0,91 $>0,05$, maka Ho diterima. Artinya tidakterdapat pengaruhkegiatan publikasi ilmiah terhadap perkembangan karier pustakaawan di Universitas Hasanuddin. Besarnya tingkat tidak signifikansinya adalah sebesar $-0,18$ atau $-18 \%$. Hasilini menggambarkan bahwa kegiatan publikasi ilmiah pustakawan tidak dapat memberikan dampak positif pada perkembangan karier pustakawan di Universitas Hasanudin Makassar.

Publikasi ilmiah merupakan suatu bentuk kegiatan penyebarluasan karya ilmiah seseorang atau kelompok dalam bentuk laporan baik hasil penelitian, makalah, buku, artikel dan lain-lain. Salah satu wujud dari profesionalisme pustakawan adalah melakukan kegiatan publikasi ilmiah. Publikasi ilmiah pustakawan berkontribusi dalam keilmuan bidang kepustakawanan, karena berbagai pengalaman kerja pustakawan dan idepengembangan perpustakaan yang ditulis pustakawan pada suatu karya ilmiah akan lebih bermanfaat jika dipublikasikan secara luas. Publikasi ilmiah pustakawan dapat meningkatkan citra profesi pustakawan, karena menulis karya ilmiah merupakan salah satu upaya pemasaran kepada publik mengenai

\footnotetext{
${ }^{38}$ Bregita RindyAntika dan Bregita Rindy Suharso, Studi PengembanganDiri (BakatMinat) pada Siswa Komunitas Sastra di Sekolah Alternatif Qoryah Thoyyibah Salatiga. Indonesian Journal of Guidance and Counseling: Theory and Aplication, Vol.2, No. 3(2013): 75-80. DOI: 10.15294/ijgc. v2i3.3191
} 
berbagai hal yang terkait dalam sebuah profesi.Menulis karya tulis ilmiah merupakan salah satu upaya pemasaran kepada publik mengenai berbagai hal yang terkait dalam sebuah profesi, tak terkecuali pustakawan. "Menulis karya ilmiah yang dipublikasikan secara luas melalui buku, artikel jurnal ilmiah maupun media massa, pustakawan dapat mempengaruhi dan menepis opini masyarakat yang masih memandang sebelah mata profesi pustakawan. Kontribusi pustakawan dalam komunikasi ilmiah bidang perpustakaan dan informasi merupakan salah satu langkah pembuktian eksistensi pustakawan dan upaya meningkatkan profesionalisme profesi pustakawan dalam dunia akademik (Novianto, 2020)". ${ }^{9}$ Selanjutnya Masriyatun (2018) mengatakan bahwa "pustakawan harus mempunyai kemampuan dalam bidang meneliti bidang kepustakawanan agar profesinya dapat lebih diakui eksistensinya di masyarakat di mana penelitian yang dilakukan dapat melalui berbagai aspek bidang ilmu perpustakaan dan informasi di sebuah perpustakaan berkaitan dengan produk informasi, sistem informasi, perilaku penelusuran informasi dan pemakai informasi itu sendiri".40

Namun variable kegiatan karya inovasi pustakawan pada table 1, diketahui bahwa nilai $\mathrm{T}_{\text {hitung }}$ karya inoatif pustakawan (X3) yaitu sebesar 2,021 , sedangkan nila $T_{\text {tabel }}$ yaitu sebesar 2,021. Data tersebut menunjukkan bahwa nilai $\mathrm{T}_{\text {hitung }} 3,128>\mathrm{T}_{\text {tabel }} 2,021$ atau nilai signifikasi0,003 $<0,05$, maka Ho ditolak, artinya terdapat pengaruh positif kegiatan karya inovatif terhadap perkembangan karier pustakawan. Besarnya tingkat signifikansinya adalah sebesar 0,45 atau $45 \%$.Hasil ini menggambarkan bahawaternyata karya inovatif pustakawan dapat memberikan dampak yang besar pada perkembangan karier pustakawan di Universitas Hasanudin.

Pustakawan kreatif inovatif adalah pustakawan yang mampu membuat program serta terobosan yang mampu membuat pemustaka sering mengunjungi perpustkaan. Pustakawan kreatif dan inovatif merupakan

\footnotetext{
${ }^{39}$ Novianto, Op. Cit, hal.

${ }^{40}$ Masriyatun, PublikasiIlmiahPustakawan: Kontribusinya pada Citra Profesi, PengembanganKarir dan TransformasillmuPengetahuan. JurnalPustakawan Indonesia, Vol. 17, No. 1(2018): 24-30. https://jurnal.ipb.ac.id/index.php/jpi/issue/view/2445
} 
pustakawan yang luar biasa. Pustakwan mampu menguraikan kompleksitas tantangan dan memikirkan berbagai alternatif tindakan yang dapat dilakukan untuk menghadapi tantangan zaman. Pustakawan kreatif inovatif selalu bekerja dengan luar biasa. Pustakawan seperti ini selalu berpan dangan positif dan orientasi pandangannya terhadap suatu persoalan merupakan kunci awal baginya untuk membangun kreativitas. Menurut Biranvand (2015: 13) dalam penelitiannya menyatakan bahwa "perpustakaan modern harus lebih kreatif dan inovatif untuk mengatasi kompleksitas komunikasi ilmiah dan berhasil menanganiteknologi informasi". "Strategi kunci untuk merajut inovasi dalam rangka optimalisasi pengembangan SDM perpustakaan perguruan tinggi agar berkualitas dan menjadi terobosan yang menantang untuk diwujudkan, salah satunya dengan embedded librarians (Fatmawati, 2016)". 42

Pandangan Lieutenant (2013) bahwa "embedded librarian adalah mensyaratkan keaktifan, partisipasi aktif, ada target capaian keluar dari perpustakaannya. Pustakawan dapat memberikan informasi terkait topik penelitian, literasi informasi, cara membuat daftar pustaka, kontak informasi yang penting, dan cara menelusur sumber informasi elektronik. Kemudian untuk suksesnya embedding librarianship dalam pembelajaran online, mencakup aspek partnership, participation, dan community". ${ }^{3}$

\subsection{Pengaruh Secara Bersama-Sama Pengembangan Profesi Pustakawan (Pengembangan Diri, Publikasi Ilmiah, dan Karya Inovatif) Terhadap Perkembangan Karier Pustakawan di Universitas Hasanuddin.}

Untuk melihat hasil penelitian pengaruh secara simultan antara pengembangan profesi (pengembangan diri, publikasi ilmiah dan karya inovatif pustakawan terhadap perkembangan karier pustakawan di Universitas Hasanuddin Makassar dapat dilihat pada tabel 2.

${ }^{41}$ Ali Biranvand, Creativity of librarians in public libraries: case study on publiclibraries of Fars Province (Iran). Library Philosophy and Practice, (2015): 1-17. https://digitalcommons.unl.edu

${ }^{42}$ Endang Fatmawati, Merajut Inovasi Perguruan Tinggi untuk Mewujudkan SDM Perpustakaan Berkualitas. Jurnal Pustakaloka, Vol. 8, No. 2(2016): 273-282. DOI: 10.21154/pustakaloka. v8i2.686.

${ }^{43}$ Elizabeth Lieutenant, Embedded Librarianship in Online Learning Environments. The Catholic University of America, Final Project Presentation, (2013. https://jurnal.iainponorogo.ac.id. 
Tabel 2. Hasil Uji F ANOVA ${ }^{a}$ Regresi

\begin{tabular}{cccccccc}
\hline \multicolumn{1}{l}{ Model } & Sum of Squares & df & Mean Square & F hitung & F Tabel & Sig. \\
\hline 1 & Regression & 3.533 & 3 & 1.178 & 5.198 & 2,82 & $.004^{\mathrm{b}}$ \\
\hline Residual & 9.743 & 43 & .227 & & & \\
\hline Total & 13.277 & 46 & & & & \\
\hline
\end{tabular}

a. Dependent Variable: Y . b. Predictors: (Constant), X3, X1, X2. Sumber: data primer, 2021

Berdasarkan hasil penelitian pada tabel 2, terlihat bahwa nilai $\mathrm{F}_{\text {hitung }}$ variabel pengembangan profesi (kegiatan pengembangan diri, publikasi ilmiah dan inovatif pustakawan) yakni sebesar 5,198 dan $\mathrm{F}_{\text {tabel }}$ sebesar 2,82, sedangkan nilaisig. 0,004 dan level of significant (0.05), karena nilai $\mathrm{F}_{\text {hitung }} 5,198$ $>\mathrm{F}_{\text {tabel }} 3,21$ atau nilai $0,004<0,05$, maka Ho di tolak. Artinya terdapat pengaruh positif secara bersama-sama pengembangan profesi terhadap perkembangan karier pustakawan di Universitas Hasanuddin. Hasil ini menggambarkan bahwa ternyata pengembangan profesi pustakawan terdiri dari: kegiatan pengembangan diri, kegiatan publikasi ilmiah, dan kegiatan karya inovasi pustakawan dapat memberikan dampak positif pada perkembangan karier pustakawan.

Sementara itu, untuk mengetahui besarnya kemampuan pengaruh yang diberikan oleh variable pengembangan profesi terdiri dari: kegiatan pengembangan diri; kegiatan publikasi ilmiah; dan kegiatan karya inovasi pustakawanterhadap perkembangan karier pustakawan di Universitas Hasanuddin dapat dilihat pada tabel 3.

Tabel 3. Model Summary

\begin{tabular}{cccccc}
\hline Model & $\mathrm{R}$ & R Square & $\begin{array}{c}\text { Adjusted R } \\
\text { Square }\end{array}$ & $\begin{array}{c}\text { Std. Error of } \\
\text { the Estimate }\end{array}$ & Durbin-Watson \\
\hline 1 & $.516^{\mathrm{a}}$ & .266 & .215 & .476 & 1.930 \\
\hline
\end{tabular}

a. Predictors: (Constant), X3, X1, X2. Dependent Variable: Y. Sumber: data primer, 2021 
Berdasarkan hasil output pada tabel 3, diperoleh nilai R2 (R Square) yakni 0,266, artinya pengembangan profesi terdiri dari: kegiatan pengembangan diri; kegiatan publikasi ilmiah; dan kegiatan karya inovasi pustakawandapat mempengaruhi perkembangan karier pustakawan sebesar $27 \%$. Sementara, sisanya $73 \%$ dipengaruhi oleh variable lain yang tidak diteliti.

Pengembangan profesi pustakawan menititikberatkan pada kegiatan penelitian, pelatihan, seminar atau workshop dan kreatif inovatif. Dalam rangka meningkatkan profesi pustakawan, maka pustakawan harus memiliki motivasi dan semangat yang tinggi dalam pengembangan profesinya. Pustakawan yang memiliki motivasi dan semangat yang tinggi dapat lebih mudah untuk meningkatkan pengembangan profesinya melalui berbagai macam kegiatan pengembangan profesi yang diikuti sehingga nantinya dapat meningkatkan kompetensi pustakawan dan mewujudkan sumber daya manusia yang berkualitas di perpustakaan. Menurut Nashihuddin (2011), "profesionalisme pustakawan mempunyai arti pelaksanaan kegiatan perpustakaan yang didasarkan pada keahlian dan rasa tanggungjawab sebagai pengelola perpustakaan. Keahlian menjadi faktor penentu dalam menghasilkan hasil kerja serta memecahkan masalah yang mungkin muncul. Sementara itu, tanggungjawab merupakan proses kerja pustakawan yang tidak semata-mata bersifat rutinitas, tetapi senantiasa dibarengi dengan upaya kegiatan yang bermutu melalu prosedur kerja yang benar".44

\subsection{Hambatan dalam pengembangan profesi pustakawan dan perkembangan karier pustakawan pustakawan di Universitas Hasanuddin.}

Untuk mengetahui hasil penelitian mengenai hambatan pengembangan profesi pustakawan di Universitas Hasanuddin dapat dilihat pada tabel 4.

${ }^{44}$ Wahid Nashihuddin, Menumbuhkan Kompetensi dan rofesionalisme Pustakawan: Sebuah Catatan", (2011). https://digilib.undip.ac.id. 


\section{Tabel 4. Penilaian Pustakawan Pustakawan Terhadap Hambatan Pengembangan Profesi}

\begin{tabular}{|c|c|c|c|c|c|c|c|c|c|c|}
\hline \multirow{3}{*}{ Indikator Pengembangan Profesi } & \multicolumn{8}{|c|}{ Kategori Penilaian } & \multirow{2}{*}{\multicolumn{2}{|c|}{$\begin{array}{l}\text { Jumlah } \\
\text { Responden }\end{array}$}} \\
\hline & \multicolumn{2}{|c|}{$\begin{array}{l}\text { Sangat } \\
\text { Setuju }\end{array}$} & \multicolumn{2}{|c|}{ Setuju } & \multicolumn{2}{|c|}{$\begin{array}{c}\text { Kurang } \\
\text { Setuju }\end{array}$} & \multicolumn{2}{|c|}{$\begin{array}{l}\text { Tidak } \\
\text { Setuju }\end{array}$} & & \\
\hline & $\mathbf{F}$ & $\%$ & $\mathbf{F}$ & $\%$ & $\mathbf{F}$ & $\%$ & $\mathbf{F}$ & $\%$ & $\mathrm{~F}$ & $\%)$ \\
\hline 1. Kurang motivasi & 7 & 15 & 28 & 58 & 11 & 23 & 2 & 4 & 48 & 100 \\
\hline 2. Kurang percaya diri & 5 & 10 & 22 & 46 & 15 & 31 & 6 & 13 & 48 & 100 \\
\hline 3. Kurang fokus & 5 & 10 & 26 & 54 & 13 & 27 & 4 & 8 & 48 & 100 \\
\hline 4. Wawasan sempit & 2 & 4 & 17 & 35 & 22 & 46 & 7 & 14 & 48 & 100 \\
\hline $\begin{array}{l}\text { 5. Tidak memiliki kemampuan } \\
\text { pengetahuan/ keterampilan }\end{array}$ & 2 & 4 & 24 & 50 & 18 & 38 & 4 & 8 & 48 & 100 \\
\hline 6. Kurangkesempatan & 3 & 6 & 20 & 42 & 21 & 44 & 4 & 8 & 48 & 100 \\
\hline 7. Terbatasnya waktu & 4 & 8 & 22 & 46 & 18 & 38 & 4 & 8 & 48 & 100 \\
\hline 8. Kurang produktivitas & 1 & 2 & 27 & 57 & 17 & 35 & 3 & 6 & 48 & 100 \\
\hline $\begin{array}{l}\text { 9. Terbatasnya anggaran dan } \\
\text { wadah }\end{array}$ & 7 & 15 & 22 & 46 & 12 & 25 & 7 & 15 & 48 & 100 \\
\hline $\begin{array}{l}\text { 10. Kurangnya perhatian dan } \\
\text { apresiasi dari pimpinan atau } \\
\text { instansi. }\end{array}$ & 3 & 6 & 21 & 44 & 17 & 35 & 7 & 15 & 48 & 100 \\
\hline
\end{tabular}

Sumber: data primer, 2021

Hasil penelitian menunjukkan bahwa dari 10 (sepuluh) indikator hambatan pengembangan profesi pustakawan di Universitas Hasanuddin terdiri dari:kurannya motivasi; kurang percaya diri; kurang fokus; wawasan sempit; tidak memiliki kemampuan atau pengetahuandan keterampilan; kurangnya kesempatan; terbatasnya waktu karena pekerjaan; kurang produktivitas karena faktor lingkungan; terbatasnya anggaran dan wadah; kurang perhatian dan apresiasi dari pimpinan atau instansi, ada 8 (delapan) indikator yang dinilai responden menyatakan setuju yakni kurangnya motivasi pustakawan; kurang percaya diri; kurang fokus; kemampuan atau pengetahuan dan keterampilan; terbatasnya waktu karena pekerjaan; kurang produktivitas karena faktor lingkungan; terbatasnya anggaran dan wadah untuk kegiatan pengembangan profesi; kurangnya perhatian dan apresiasi 
dari pimpinan atau instansi.Sementara itu, 2 (dua) indikator yang menyatakan kurang setuju yaitu pustakawan kurang memiliki kesempatan dan memiliki wawasan sempit dalam melakukan kegiatan pengembangan profesi di Universitas Hasanuddin. Hasil ini menggambarkan bahwa pengembangan profesi pustakawan seperti kurangnya motivasi pustakawan; kurang percaya diri; kurang fokus; kemampuan atau pengetahuan dan keterampilan; terbatasnya waktu karena pekerjaan; kurang produktivitas karena faktor lingkungan; terbatasnya anggaran dan wadah untuk kegiatan pengembangan profesi; kurangnya perhatian dan apresiasi dari pimpinan atau instansi bukan merupakan hambatan dalam kegiatan pengembangan profesi. Sedangkan, pustakawan kurang memiliki kesempatan dan memiliki wawasan sempit dalam melakukan kegiatan pengembangan profesi di Universitas Hasanuddin merupakan hambatan.

"Pengembangan profesionalisme, yang mana menitikberatkan pada kegiatan pelatihan ataupun seminar tentang pustakawan dan ilmu perpustakaan serta keterlibatan dalam organisasi profesi yang diharapkan dapat meningkatkan kompetensi. Hal tersebut kembali lagi mengungkapkan pemahaman bahwa tugas dan peran administratif merupakan kunci utama dalam peningkatan kompetensi, peran bahkan kinerja pustakawan. Upaya pengembangan profesionalisme pustakawan dapat dilakukan dengan meningkatkan kompetensinya. Salah satu konsep pengembangan profesionalisme pustakawan, sebagaimana disebut International Federation of Library Association (IFLA) selaku federasi internasional perpustakaan, adalah melalui $\mathrm{CPD}$, namun demikian penerapan konsep tersebut dalam pengembangan profesionalisme pustakawan di perguruan tinggi pada umumnya masih kurang mendapat perhatian (Widodo, 2015)".45

Untuk mengetahuan hasil penelitian mengenai hambatan perkembangan karier pustakawan di Universitas Hasanuddin dapat dilihat pada table 5 .

${ }^{45}$ Suparno Eko Widodo, Manajemen Pengembangan Sumber Daya Manusia. (Jakarta: Pustaka Pelajar, 2015). 


\section{Tabel 5. Penilaian Pustakawan Terhadap Hambatan Pengembangan Karier}

\begin{tabular}{|c|c|c|c|c|c|c|c|c|c|c|}
\hline \multirow{3}{*}{ Indikator Pengembangan Profesi } & \multicolumn{8}{|c|}{ Kategori Penilaian } & \multirow{2}{*}{\multicolumn{2}{|c|}{$\begin{array}{l}\text { Jumlah } \\
\text { Responden }\end{array}$}} \\
\hline & \multicolumn{2}{|c|}{$\begin{array}{l}\text { Sangat } \\
\text { Setuju }\end{array}$} & \multicolumn{2}{|c|}{ Setuju } & \multicolumn{2}{|c|}{$\begin{array}{l}\text { Kurang } \\
\text { Setuju }\end{array}$} & \multicolumn{2}{|c|}{$\begin{array}{l}\text { Tidak } \\
\text { Setuju }\end{array}$} & & \\
\hline & $\mathrm{F}$ & $\%$ & $\mathrm{~F}$ & $\%$ & $\mathrm{~F}$ & $\%$ & $\mathrm{~F}$ & $\%$ & $\mathrm{~F}$ & $(\%)$ \\
\hline 1. Tidak yakin kompetensi diri & 3 & 6 & 15 & 31 & 20 & 42 & 10 & 21 & 48 & 100 \\
\hline 2. Kurangnya bertanggungjawab & 1 & 2 & 11 & 23 & 21 & 44 & 15 & 31 & 48 & 100 \\
\hline $\begin{array}{l}\text { 3. Kurangnya kekuatan atau } \\
\text { kemampuan }\end{array}$ & 2 & 4 & 13 & 27 & 21 & 44 & 12 & 25 & 48 & 100 \\
\hline $\begin{array}{l}\text { 4. Tidak mampu mengumpulkan } \\
\text { angka kredit }\end{array}$ & 1 & 2 & 23 & 48 & 18 & 38 & 6 & 12 & 48 & 100 \\
\hline 5. Kurangnya promosi & 0 & 0 & 19 & 34 & 22 & 46 & 7 & 15 & 48 & 100 \\
\hline $\begin{array}{l}\text { 6. Merasa puas dengan jabatan } \\
\text { yang dimiliki }\end{array}$ & 3 & 6 & 22 & 46 & 16 & 33 & 7 & 15 & 48 & 100 \\
\hline 7. Kurangnya kerjasama & 1 & 2 & 26 & 54 & 14 & 29 & 7 & 15 & 48 & 100 \\
\hline
\end{tabular}

Suber: data primer, 2021

Hasil penelitian menunjukkan bahwa dari 7 indikator hambatan perkembangan karier pustakawan di Universitas Hasanuddin terdri dari: tidak yakin dengan kompetensi; kurangnya tanggungjawabseperti malas, suka terlambat, sering tidak berada di kantor; kurangnya kekuatan dan kemampuan; tidak mampu mengumpulkan kredit yang disyaratkan sesuai dengan tupoksi jabatannya; merasa puas dengan jabatan yang dimiliki; kurangnya kerjasama atau jaringan yang mendukung di lingkungannya, ada 4 (empat) indikatoryang dinilai responden menyatakan kurang setuju yakni tidak yakin dengan kompetensi pustakawan; kurangnya tanggung jawab seperti malas, suka terlambat, sering tidak berada dikantor; kurangnya kekuatan atau kemampuan; dan kurangnya informasi dalam peluang promosi. Sementara itu, 3 indikator lainnya yakni kurangnya kekuatan atau kemampuan, merasa puas dengan jabatan yang dimiliki, kurangnya kerjasama atau jaringan yang mendukung di lingkungannya menyatakansetuju.Hasil ini menggambarkan bahwa 4 (empat) indikator yakni tidak yakin dengan kompetensi pustakawan;kurangnya tanggung 
jawab seperti malas, suka terlambat, sering tidak berada dikantor; kurangnya kekuatan atau kemampuan; dan kurangnya informasi bukan merupakan hambatan bagi pustakawan dalam perkembangan kariernya. Sementara, 3 (tiga) indikator lainnya yakni kurangnya kekuatan atau kemampuan; merasa puas dengan jabatan yang dimiliki; kurangnya kerjasama atau jaringan yang mendukung di lingkungannya merupakan hambatan bagi pustakawan dalam perkembangan karier di Universitas Hasanudin.

Pengembangan karier pustakawan sangat penting karena tuntutan pekerjaan dan jabatan, sebagai akibat kemajuan teknologi dan semakin ketatnya peraturan pemerintah tentang jabatan fungsional tertentu. Pengembangan karier pustakawan bisa dilakukan melalui 2 jalur, yakni melalui pendidikan dan latihan (Diklat) dan melaksanakan tugas atau pekerjaan kepustakawanan. Pelaksanaan perkembangan karier dapat terwujud sesuai yang direncanakan apabila pustakawan memilki kompetensi, kepedulian, promosi, wadah dan minat. Pengembangan karier pegawai bisa diwujudkan apabila promosi didasarkan pada pertimbangan- pertimbangan yang obyektif, rasional, dan diketahui secara luas dikalangan pegawai. Kepedulian adalah memberikan umpan balik kepada para pegawai tentang pelaksanaan tugas masing-masing, sehingga para pegawai mengetahui potensi yang perlu dikembangkan dan kelemahan yang perlu diatasi dan ini sudah berjalan sesua dengan standar secara prosedural. Para pegawai umumnya mengharapkan bahwa mereka mempunyai akses terhadap informasi tentang berbagai peluang untuk dipromosikan. Akses ini sangat penting terutama apabila lowongan yang tersedia di isi melalui proses seleksi internal yang sifatnya kompetitif. Pendekatan yang tepat digunakan dalam pengembangan karir adalah menimbulkan minat para pekerja untuk pengembangan karir adalah pendekatan fleksibel dan proaktif. Kepuasan pegawai dalam pengembangan karir ditentukan apabila pegawai tersebut dalam melaksanakan tugas yang dibebankan kepadanya dapat dipertanggung jawabkan dengan baiksecara moril maupun materil (Muahajir, 2015). ${ }^{46}$

${ }^{46}$ Muhammad Muhajir, Analisis Pengembangan Karir Pegawai pada Kantor Dinas Pendapatan Daerah Provinsi Sulawesi Tengah. e-Jurnal Katalogis, Vol. 3, No. 12(2015): 142-149. 


\section{KESIMPULAN}

Berdasarkan hasil penelitian dan pembahasan menyimpulkan bahwa secara parsial kegiatan pengembangan profesi meliputi pengembangan diri dan publikasi ilmiah tidak berpengaruh atau tidak memberikan dampak positif terhadap perkembangan karier pustakawan di Universitas Hasanuddin. Sementara itu, kegiatan karya inovatif pustakawan berpengaruh atau dapat memberikan dampak positif terhadap perkembangan karier pustakawan di Universitas Hasanuddin. Kemudian secara simultan bahwa kegiatan pengembangan profesi pustakawan berpengaruh atau dapat memberikan dampak positif terhadap perkembangan karier pustakawan di Universitas Hasanuddin.

Hambatan pustakawan dalam pengembangan profesi adalah kurangnya motivasi pustakawan; kurang percaya diri; kurang fokus; kemampuan atau pengetahuan dan keterampilan; terbatasnya waktu karena pekerjaan; kurang produktivitas karena faktor lingkungan; terbatasnya anggaran dan wadah untuk kegiatan pengembangan profesi; kurangnya perhatian dan apresiasi dari pimpinan atau instansi. Sementara itu, kurangnya kesempatan dan wawasan sempit bukan merupakan hambatan. Selanjutnya, hambatan pustakawan dalam pengembangan karier adalah kurangnya kekuatan atau kemampuan, merasa puas dengan jabatan yang dimiliki, kurangnya kerjasama atau jaringan yang mendukung di lingkungannya. Sementara itu, tidak yakin dengan kompetensi pustakawan, kurangnya tanggung jawab seperti malas, suka terlambat, sering tidak berada dikantor; kurangnya kekuatan atau kemampuan; dan kurangnya informasi bukan merupakan hambatan bagi pustakawan dalam kegiatan perkembangan karier.

\section{SARAN DAN UCAPAN TERIMA KASIH}

Saran yang diajukan sebagai solusi, yaitu 1) Universitas Hasanuddin perlu memberikan sosialisasi dan pelatihan tentang pengetahuan bagi pustakawan pentingnya melakukan kegiatan pengembangan diri dan publikasi ilmiah, dan kegiatan karya inovatif; 2) pustakawan perlu 
membangun kejasama sesama antar pustakawan untuk saling memotivasi. 3) Untuk meminimalisir hambatan-hambatan dalam kegiatan pengembangan profesi dan perkembangan karier pustakawan, maka pihak universitas selalu melaksanakan pelatihan khususnya penulisan karya ilmiah yang tepat sasaran dan dapat dipublikasikan di jurnal cetak atau elektronik; 4) menyiapkan anggaran dan wadahnya pelatihan atau diklat pembuatan bukti fisik tupoksi setiap jabatan dalam pengumpulan angka kredit untuk kenaikan jabatan atau golongan; 5) Pustakawan harus membangun kreativitas inovatif dan produktivitasnya dalam rangka meningkatkan karier dan kualitas layanan perpustakaan. 6) UPT Perpustakaan perlu melakukan penguatan kelembagaan dalam rangka terwujudnya kegiatan pengembangan profesi dan perkembangan karier pustakawan.

Terima kasih disampaikan kepada pimpinan Universitas Hasanuddin, Kepala UPT Perpustakaan atas kesempatan dan biaya yang diberikan untuk melakukan kegiatan pengembangan profesi, serta kepada para pustakawan yang telah meluangkan waktunya untuk mengisi kuesioner dan memberikan akses data penelitian.

\section{DAFTAR PUSTAKA}

Abdan, Fahrizandi. 2018. Problematika Pustakawan dalam Menulis Karya Tulis Ilmiah Fahrizandi Abdan. Jurnal Libraria, Vol.6, No.1: 2350. DOI: 10.21043/libraria.v6i1.2215.

Antika, Bregita Rindy dan Suharso, Eko Nusantoro. 2013. Studi Pengembangan Diri (Bakat Minat) pada Siswa Komunitas Sastra di Sekolah Alternatif Qoryah Thoyyibah Salatiga. Indonesian Journal of Guidance and Counseling: Theory and Aplication, Vo.2, No. 3: 75-80. DOI: 10.15294/ijgc.v2i3.3191.https://journal.unnes.ac.id/sju/index. php/ jbk/article/view/3195.

Ariomerebi, Iroaganachi Mercy and Ifeakachuku, Enwefa. (2013). Interest and Self Motivation as Correlates Capacity Building and Career Comitment: a Study of Librarians in Nigeria. Brazilian Journal of 
Information Science: Research Trends, Vol. 7, No. 2: 29-46. From https://www.proquest.com.

Biranvand, Ali. 2015. Creativity of librarians in public libraries: case study on publiclibraries of Fars Province (Iran). Library Philosophy and Practice, 1-17. https://digitalcommons.unl.edu.

Fatmawati, Endang. 2016. Merajut Inovasi Perguruan Tinggi untuk Mewujudkan SDM Perpustakaan Berkualitas. Jurnal Pustakaloka, Vol. 8, 2: 273-282. DOI: 10.21154/pustakaloka.v8i2.686.

Igere, Mercy Arodovwe; Adomi, Esharenana; Nwosu, Cyril Obiora. 2020. The predictive nature of work motivation and career commitment of librarians in Universities in Southern Nigeria. Library Philosophy and Practice; Lincoln, 1-24. https://www.proquest.com.

Ismanto. 2019. Pengembangan Profesi Pustakawan Menuju Kinerja Profesional.Perpustakaan Universitas Islam Indonesia. Buletin Perpustakaan Universitas Islam Indonesia, Vol.2, No. 2:151-160. https:// journal.uii.ac.id/Buletin-Perpustakaan/article/ view/15188/10086.

Istiana, Purwani. 2017. Pustakawan Berkualitas Tinggi: Urgensi Perpustakaan Perguruan Tinggi sebagai "fountain of Knowledge". Jurnal Ilmu Perpustakaan dan Informasi, Vol. 2, No. 1: 107-114. DOI: 10.30829/ jipi.v2i1.924. Diakases dari: http://jurnal.uinsu.ac.id/index.php/jipi/ issue/view/

Kadarisman, Muh. (2018). Analisis Pengembangan Karier Aparatur Sipil Negara di Pemerintahan Kota Depok. E-Journal BKN, Vol. 12, No. 2: 115-138. https://jurnal.bkn.go.id/index.php/asn/article/view/29

Lieutenant, Elizabeth. 2013. Embedded Librarianship in Online Learning Environments. The Catholic University of America, Final Project Presentation. https://jurnal.iainponorogo.ac.id.

Masriyatun. (2018).Publikasi Ilmiah Pustakawan: Kontribusinya pada Citra Profesi, Pengembangan Karir dan Transformasi Ilmu Pengetahuan. Jurnal Pustakawan Indonesia, Vol. 17, No. 1: 24-30. https://jurnal.ipb. ac.id/index.php/jpi/issue/view/2445. 
Menpan-RB. 2014. Peraturan Menteri Pendayaan Aparatur Negara dan Reformasi Birokrasi Nomor 9 Tahun 2014 Tentang Jabatan Fungsional Pustakawan Dan Angka Kreditnya. Jakarta: Kementerian Pendayagunaan Aparatur Negara dan Reformasi Birokrasi Republik Indonesia.

Muhajir, Muhammad. 2015. Analisis Pengembangan Karir Pegawai pada Kantor Dinas Pendapatan Daerah Provinsi Sulawesi Tengah. e-Jurnal Katalogis, Vol. 3, No. 12: 142-149.https://media.neliti.com/media/ publications/150261/

Nashihuddin, Wahid. 2011. Menumbuhkan Kompetensi dan rofesionalismePustakawan: Sebuah Catatan”. Diakses dari: https:// digilib.undip.ac.id.

Novianto, Achmad Qorni. 2020. Publikasi ilmiah pustakawan: kontribusinya pada citra profesi, pengembangan karir dan transformasi ilmu pengetahuan. Jurnal Almaktabah, Vol. 5, No. 1: 59-74.DOI:10.29300/ mkt.v5i1.2877. Diakses dari: https://ejournal.iainbengkulu.ac.id/ index.php/almaktabah/ article/view/2877.

Perpustakaan Nasional Republik Indonesia. Pedoman Penyelenggaraan Perpustakaan Perguruan Tinggi Tahun 2015.

Perpustakaan Nasional Republik Indonesia. 2015. Peraturan Kepala Perpustkaan Republik Indonesia Nomor 11 Tahun 2015 tentang Petunjuk Teknis Jabatan Fungsional Pustakawan dan Angka Kreditnya. Jakarta: Perpustakaan Nasional Republik Indonesia.

Rivai, Veithzal. 2014. Manajemen Sumber Daya Manusia Untuk Perusahaan: Dari Teori ke Praktek. Jakarta: RajaGrafindo Persada.

Rohmah, Wafrotur. (2016). Upaya Meningkatkan Pengembangan Keprofesian Berkelanjutan Dalam Peningkatan Profesionalisme Guru. Makalah Seminar Nasional Pendidikan: 1-21.https://publikasiilmiah.ums.ac.id/ handle/11617/7267.

Siagian, Sondang P. 2012. Manajemen Stratejik. Jakarta: Bumi Aksara Septiyanti, Elvrin et al. 2018. Penyuluhan Pengembangan Keprofesian 
Berkelanjutan bagi Guru se-Kecamatan Bangkinang Kabupaten Kampar. Wahana Dedikasi, Vol. 1 No. 2. Diakses dari: https://garuda. ristekbrin.go.id

Sugiharjo, R. Joko dan Rustinah. 2017. Pengaruh Perencanaan Karir, Pengembangan Karir Karyawan, dan Kompensasi terhadap Kinerja Karyawan pada Jambuluwuk Puncak Resort. Jurnal Ilmiah Manajemen dan Bisnis, Vol. 3, No. 3: 444-454. DOI: 10.22441/jimb.v3i3.3864. https://garuda.ristekbrin.go.id/journal/view/.

Syahrir. 2019. Innovation Librarian as a Agent of Change in Developing Library in Era Information. Al Maktabah Jurnal kajian Ilmu dan Perpustakaan, Vol. 4, No. 2. DOI: 10.29300/mkt.v4i2.2519. Diakses dari: https://ejournal.iainbengkulu.ac.id/index.php/almaktabah/ issue/view/291

Widodo, Suparno Eko. 2015. Manajemen Pengembangan Sumber Daya Manusia. Jakarta: Pustaka Pelajar.

Wuryandini, Endang. 2014. Analisis Permasalahan dan Kebutuhan Pengembangan Keprofesian Berkelanjutan Guru SMK Bidang Keahlian Bisnis dan Manajemen Pascasertifikasi di Kota Semarang. Jurnal Manajemen Pendidikan, Vol. 9, No. 2: 108-119. Diakses dari https://journals.ums.ac.id/

Yuniwati dan Fitriani, Laila Nur. 2013. Pengaruh SK Menpan Nomor 132/ Kep/M. PAN/12/2002 tentang Jabatan Fungsional Pustakawan dan Angka Kreditnya terhadap Produktivitas Karya Ilmiah Pustakwan Universitas Diponegoro. Jurnal Ilmu Perpustkaan, Vol. 2, No. 2:39-48. http://ejournal-sl.undip.ac.id/index.php/jip.

Zulbahri. 2020. Pengaruh Pengeambangan Karir dan Disiplin Kerja terhadap Kepuasan Kerja dan Kinerja ASN Studi Kasus di SMK 2 Kota Bima (Suatu Kajian Studi Literatur Manajemen Sumber Daya Manusia). Jurnal Manajemen Pendidikan dan Ilmu Sosial, Vol. 1, No. 2: 622642. DOI: 10.38035/jmpis.v1i2.398. https://garuda.ristekbrin.go.id/ journal/view/ 
Darmiati, Darmawari Nembo, Sri Junandi 